\title{
WASPADA PNEUMOKONIOSIS PADA PEKERJA DI INDUSTRI PERTAMBANGAN
}

\author{
Nur Nunu P.Sinaga ${ }^{1}$,Patar Hutagalung ${ }^{2}$, Jumaini Andriana ${ }^{3}$ \\ 1. Departemen Biokimia FK UKI \\ 2. Kemnaker RI \\ 3. Departemen Anatomi FK UKI \\ Email: nunuprihantini23@gmail.com
}

\begin{abstract}
ABSTRAK
Pneumokoniosis adalah penyakit akibat kerja yang kronik akibat menghirup debu dalam waktu yang lama dengan ditandai adanya inflamasi dari alveolus. Data dari WHO (World Health Organization) menyatakan bahwa terdapat 1,1 juta kematian oleh penyakit akibat kerja di seluruh dunia, 5\% dari angka tersebut adalah pneumokoniosis. Paparan dari suatu proses industrialisasi ini dapat menyebabkan penyakit akibat kerja. National Institute for Occupational Safety and Health (NIOSH) di Amerika Serikat menyatakan bahwa penyakit pernapasan merupakan penyakit urutan pertama dari sepuluh besar penyakit akibat kerja salah satunya berkaitan dengan paruparu. Badan dunia International Labour Organization (ILO) menyatakan bahwa penyakit paru akibat kerja yang paling banyak diderita oleh pekerja adalah penyakit paru restriktif yakni pneumokoniosis, di negara berkembang penderitanya sekitar 30\% hingga 50\%. Data penyakit akibat kerja Dinas Kesehatan Provinsi Jawa Tengah,berdasarkan data hasil survey pemeriksaan fungsi paru pada tahun 2004 mendapati bahwa 83,75\% pekerja formal dan 95\% pekerja informal mengalami gangguan fungsi paru. Reaksi paru terhadap debu mineral tergantung pada banyakfaktor, termasuk ukuran, bentuk dan kelarutan dan reaktivitas partikel. Jenis pneumoconiosis tergantung dari jenis pajanan debu seperti silika, asbes, berillium. Ada tiga kriteria mayor yang dapat membantu untuk diagnosis pneumokoniosis yaitu 1. pajanan debu yang signifikan, 2. gambaran spesifik penyakit terutama kelainan radiologis. 3. Pneumokoniosis mirip dengan penyakit interstitial paru difus. Pencegahan adalah menjauhi dari pajanan serta para pekerja wajib melakukan pemeriksaan secara berkala.
\end{abstract}

Kata kunci: Pneumokoniosis, pekerja tambang, debu

\begin{abstract}
Pneumoconiosis is a chronic work-related disease caused by inhaling dust for a long time with the presence of inflammation from the alveoli. Data from WHO (World Health Organization) states that there are 1.1 million deaths from occupational diseases worldwide, $5 \%$ of which are pneumoconiosis. Exposure to an industrialization process can cause occupational diseases. The National Institute for Occupational Safety and Health (NIOSH) in the United States states that respiratory illness is the first in the top ten occupational diseases, one of which is related to the lungs. The World Agency for International Labor Organization (ILO) states that the most common occupational lung disease suffered by workers is restrictive pulmonary disease, pneumoconiosis, in which developing countries suffer from around $30 \%$ to 50\%. Data on occupational illnesses from the Central Java Provincial Health Office, based on data from a survey of lung function examinations in 2004, found that $83.75 \%$ of formal workers and $95 \%$ of informal workers experienced lung function disorders. The reaction of the lung to mineral dust depends on many factors, including the size, shape and solubility and reactivity of the particles. The type of pneumoconiosis depends on the type of dust exposure such as silica, asbestos, beryllium. There are three major criteria that can help for the diagnosis of pneumoconiosis, namely 1. significant dust exposure, 2. specific features of the disease, especially radiological abnormalities. 3. Pneumoconiosis is similar to diffuse pulmonary interstitial disease. Prevention is to stay away from exposure and workers must carry out periodic checks.
\end{abstract}

Keywords: pneumoconiosis, miners, dust 


\section{PENDAHULUAN}

Para pekerja di Indonesia ini dewasa ini banyak yang belum memperhatikan lingkungan kerja yang seharusnya dapat mengurangi kondisi penyakit akibat kerja. Seharusnya dalam melakukan perkerjaan para pekerja mempersiapkan diri untuk melindungi tubuhnya dari paparan debu maupun benda - benda asing.

Data dari WHO (World Health Organization) menyatakan bahwa terdapat 1,1 juta kematian oleh penyakit akibat kerja di seluruh dunia, 5\% dari angka tersebut adalah pneumokoniosis. Paparan dari suatu proses industrialisasi ini dapat menyebabkan penyakit akibat kerja.

National Institute for Occupational Safety and Health (NIOSH) di Amerika Serikat menyatakan bahwa penyakit pernapasan merupakan penyakit urutan pertama dari sepuluh besar penyakit akibat kerja salah satunya berkaitan dengan paruparu. ${ }^{1}$

\section{Badan dunia International Labour Organization (ILO) menyatakan bahwa penyakit paru akibat kerja yang paling banyak diderita oleh pekerja adalah penyakit paru restriktif yakni pneumokoniosis, di negara berkembang penderitanya sekitar $30 \%$ hingga $50 \%{ }^{7}$ Data penyakit akibat kerja Dinas Kesehatan Provinsi Jawa Tengah,}

berdasarkan data hasil survey pemeriksaan fungsi paru pada tahun 2004 mendapati bahwa 83,75\% pekerja formal dan 95\% pekerja informal mengalami gangguan fungsi paru. ${ }^{2}$

\section{METODOLOGI PENELITIAN}

Megtode yang digunakan dengan pendekatan deskriptif eksploratif, adalah dengan studi kasus yang bersifat objektif analitis sistematis.

\section{HASIL DAN PEMBAHASAN}

Istilah pneumokoniosis berasal dari bahasa yunani yaitu "pneumo" berarti paru dan "konis" berarti debu. Terminologi pneumokoniosis pertama kali digunakan untuk menggambarkan penyakit paru yang berhubungan dengan inhalasi debu mineral. ${ }^{3}$

International Labour Organization (ILO) mendefinisikan pneumokoniosis sebagai suatu kelainan yang terjadi akibat penumpukan debu dalam paru yang menyebabkan reaksi jaringan terhadap debu tersebut. Reaksi utama akibat pajanan debu di paru adalah fibrosis. ${ }^{4}$

Ini termasuk kelompok penyakit yang luas, termasuk asma kerja, penyakit paru obstruktif kronik (PPOK), bronkhiolitis obliterans, cedera inhalasi, penyakit paru interstisial (seperti pneumokoniosis, pneumonitis hipersensitivitas, fibrosis paru), 
infeksi, kanker paru-paru dan mesothelioma. Penyakit-penyakit ini dapat disebabkan secara langsung atau karena respons imunologis terhadap paparan berbagai debu, bahan kimia, protein atau organisme.,

\section{Patogenesis}

Reaksi paru terhadap debu mineral tergantung pada banyak faktor, termasuk ukuran, bentuk dan kelarutan dan reaktivitas partikel. Sebagai contoh, partikel yang lebih besar dari 5 sampai $10 \mu \mathrm{m}$ kecil kemungkinan mencapai saluran nafas distal sedangkan partikel yang lebih kecil dari 0.5 $\mu \mathrm{m}$ cenderung berperilaku seperti gas dan keluar masuk alveolus, sering tanpa mengendap atau menyebabkan cedera. Partikel berukuran 1 sampai $5 \mu \mathrm{m}$ paling berbahaya karena menumpuk percabangan saluran distal. ${ }^{7}$

Debu batu bara relatif inert, sehingga diperlukan pengendapan dalam jumlah besar di paru sebelum timbul gejala klinis. Silika, asbestos, dan berilium lebih reaktif terhadap debu batu bara, menyebabkan reaksi fibrotik pada konsentrasi yang lebih rendah .

Faktor utama yang berperan pada patogenesis pneumokoniosis adalah partikel debu dan respons tubuh khususnya saluran napas terhadap partikel debu tersebut. ${ }^{7}$
Komposisi kimia, sifat fisis, dosis dan lama pajanan menentukan dapat atau mudah tidaknya terjadi pneumokoniosis. Patogenesis pneumokoniosis dimulai dari respons makrofag alveolar terhadap debu yang masuk ke unit respirasi paru. Terjadi fagositosis debu oleh makrofag dan proses selanjutnya sangat tergantung pada sifat toksisitas partikel debu ${ }^{7}$.

Reaksi jaringan terhadap debu bervariasi menurut aktivitas biologi debu. Jika pajanan terhadap debu anorganik cukup lama maka timbul reaksi inflamasi awal. Gambaran utama inflamasi ini adalah pengumpulan sel di saluran napas bawah. Alveolitis dapat melibatkan bronkiolus bahkan saluran napas besar karena dapat menimbulkan luka dan fibrosis pada unit alveolar yang secara klinis tidak diketahui. Sebagian debu seperti debu batubara tampak relatif inert dan menumpuk dalam jumlah relatif banyak di paru dengan reaksi jaringan yang minimal. Debu inert akan tetap berada di makrofag sampai terjadi kematian oleh makrofag karena umurnya, selanjutnya debu akan keluar dan difagositosis lagi oleh makrofag lainnya, makrofag dengan debu di dalamnya dapat bermigrasi ke jaringan limfoid atau ke bronkiolus dan dikeluarkan melalui saluran napas. Pada debu yang bersifat sitoktoksik, partikel debu yang 
difagositosis makrofag akan menyebabkan kehancuran makrofag tersebut yang diikuti dengan fibrositosis. ${ }^{4}$

Sebagian besar debu yang terhirup ditangkap oleh lapisan mucus serta mudah dikeluarkan dari paru oleh gerakan silia. Menurut Lipscomb, partikel debu akan merangsang makrofag alveolar untuk mengeluarkan produk yang merupakan mediator suatu respons peradangan dan memulai proses proliferasi fibroblast dan deposisi kolagen. Mediator yang paling banyak berperan pada patogenesis pneumokoniosis adalah Tumor Necrosis Factor (TNF)- $\alpha$, Interleukin (IL)-6, IL-8, platelet derived growth factor dan transforming growth factor (TGF)- $\beta$. Sebagian besar mediator tersebut sangat penting untuk proses fibrogenesis. Mediator makrofag penting yang bertanggung jawab terhadap kerusakan jaringan. ${ }^{4,7}$

Sitokin telah terbukti berperan dalam patogenesis pneumokoniosis. Sitokin yang dihasilkan oleh makrofag alveolar dalam merespon partikel debu yang masuk ke paru yang selanjutnya menyebabkan fibrosis pada jaringan interstitial paru. Sitokin ini terdiri atas faktor fibrogenesis seperti $T N F-\alpha$, $P D G F, I G F-1$ dan fibronektin serta faktor proinflamasi seperti $L B T 4, I L-8, \quad I L-6$, MIPIa. Disamping proses fagositosis debu oleh makrofag alveolar, yang lebih penting adalah interstisialisasi partikel debu tersebut. Bila partikel debu telah difagositosis oleh makrofag dan ditransfer ke sistem mukosilier maka proses pembersihan debu yang masuk dalam saluran napas dikategorikan berhasil. Epitel akibat pelepasan mediator inflamasi alveolar merupakan kejadian awal proses fibrogenesis di interstitial paru. Bila partikel debu telah masuk dalam interstitial maka nasibnya ditentukan oleh makrofag interstitial, difagositosis untuk kemudian di transfer ke kelenjar getah bening mediastinum atau terjadi sekresi me diator inflamasi kronik pada interstitial. Sitokin yang dilepaskan di interstitial seperti $P D G F$, $T G F, T N F, I L-1$ menyebabkan proliferasi fibroblas dan terjadilah pneumokoniosis. Sifat toksisitas debu menentukan reaksi jaringan yang terjadi pada pneumokoniosis. Debu silika dan asbes mempunyai efek biologis yang sangat kuat.

Reaksi parenkim dapat berupa fibrosis nodular yaitu contoh klasik dari silikosis, fibrosis difus pada asbestosis dan pembentukan makula dengan emfisema fokal akibat debu batubara. ${ }^{4}$ 
Tabel.1 Beberapa Jenis

Pneumokoniosis Berdasarkan Debu

Penyebabnya Jenis Debu ${ }^{4}$

\begin{tabular}{|l|l|}
\hline Asbes & Asbestosis \\
\hline Silika & Silikosis \\
\hline Batubara & $\begin{array}{l}\text { Pneumokoniosis } \\
\text { Batubara }\end{array}$ \\
\hline Besi & Siderosis \\
\hline Berilium & Beriliosis \\
\hline ]Timah & Stanosis \\
\hline Aluminium & Aluminosis \\
\hline
\end{tabular}

Tabel 2. Penyakit paru yang dipicu oleh debu mineral ${ }^{7}$

\begin{tabular}{|c|c|c|}
\hline Zat & penyakit & Pajanan \\
\hline $\begin{array}{l}\text { Debu } \\
\text { batu bara }\end{array}$ & $\begin{array}{l}\text { Pneumo } \\
\text { koniosis } \\
\text { Buruh } \\
\text { tambang } \\
\text { batubara } \\
\text { sederhan } \\
\text { a } \\
\text { Makula } \\
\text { dan } \\
\text { nodu } \\
\text { Pneumo } \\
\text { koniosis } \\
\text { buruh } \\
\text { tambang } \\
\text { batu } \\
\text { bara } \\
\text { komplek } \\
\text { s PMF } \\
\text { Sindrom } \\
\text { Caplan }\end{array}$ & $\begin{array}{l}\text { tambang } \\
\text { batu bara }\end{array}$ \\
\hline Silika & $\begin{array}{l}\text { silikosis } \\
\text { akut, } \\
\text { silikosis } \\
\text { kronik } \\
\end{array}$ & $\begin{array}{l}\text { penyempro } \\
\text { tan pasi } \\
\text { untuk } \\
\text { membersih }\end{array}$ \\
\hline Asbes & $\begin{array}{l}\text { Asbesto } \\
\text { sis, } \\
\text { Sindrom } \\
\text { Caplan }\end{array}$ & $\begin{array}{l}\text { Pertamba } \\
\text { ngan }\end{array}$ \\
\hline
\end{tabular}

\begin{tabular}{|l|l|l|}
\hline Berilium & $\begin{array}{l}\text { Berilliosi } \\
\text { s akut }\end{array}$ & $\begin{array}{l}\text { Industri } \\
\text { pesawat } \\
\text { udara }\end{array}$ \\
\hline
\end{tabular}

\section{Asbestosis dan penyakit yang disebabkan Asbes ${ }^{7}$}

Asbes adalah sekelompok silikat hidrat Kristal dengan geometri fibrosa . Berdasarkan studi epidemiologi, pajanan asbes di tempat kerja di laporkan menyebabkan :

1. Fibrosis interstitium parenkim

2. Karsinoma bronkogenik

3. Efusi pleura

4. Plak fibrosa local

5. Mesotelioma peritoneuk dan pleura maligna

6. Karsinoma laring.

Asbes dapat mempengaruhi tubuh bila serat-seratnya terhirup. Sekali terhirup, serat tersebut akan bertahan di dalam jaringan paru. Asbestosis merupakan penyakit akibat kerja yang disebabkan oleh paparan serat asbes dalam jangka waktu lama.. Efek utamanya yaitu timbulnya jaringan parut pada paru dan sesak nafas. Efek ini memburuk secara perlahan bersamaan dengan berkembangnya penyakit, sekalipun paparan sudah tidak terjadi lagi ${ }^{24}$.

Terdapat 2 bentuk asbes yang berbeda : serpentin seratnya ikal dan dan lentur yang merupakan bentuk tersering 
dari asbes yang banyak digunakan pada industri dan amfibol seratnya lurus dan kaku dan jarang ditemukan dalam industri. Meskipun berbeda, kedua bentuk asbes tersebut bersifat fibrogenik dan pajanan semakin besar akan menimbulkan penyakit akibat asbes. ${ }^{7}$

Nilai Ambang Batas Paparan terhadap asbes harus dicegah sebisa mungkin. Nilai ambang batas serat asbes yang masih diperkenankan di tempat kerja adalah tidak melebihi dari 0,1 serat/mL. Pengukuran dan pengontrolan sebaiknya dinilai ulang ketika monitoring udara mengindikasikan levelnya melebihi 0,01 serat/mL. ${ }^{24}$

\section{Pneumokoniosis Batu Bara}

Pneumokoniosis adalah CWP (Coal Workers Pneumokoniosis). CWP adalah pneumokoniosis yang disebabkan oleh inhalasi partikel karbon dari batu bara (coal), graphite atau carbon black (karbon hitam). Kelainan ini terjadi pada pekerja tambang batu bara, penambang graphite dan pekerja pabrik graphite sintetik dan pabrik karbon hitam. $^{3}$ Saluran pernapasan merupakan bagian yang paling tersering mengalami penyakit akibat kerja yang disebabkan akibat penumpukan debu yang tinggi di paru dapat menyebabkan kelainan dan kerusakan paru.
Penyakit akibat penumpukan debu pada paru disebut pneumoconiosis. Salah satu bentuk kelainan paru yang bersifat menetap adalah berkurangnya elastisitas paru, yangditandai dengan penurunan pada kapasitas vital paru. ${ }^{5}$ Diantara semua penyakit akibat kerja, 10\%$30 \%$ adalah penyakit paru. International Labour Organization (ILO) mendeteksi bahwa sekitar 40.000 kasus baru pneumoconiosis terjadi di seluruh dunia setiap tahun. Di Inggris pada tahun 1996 ditemukan 330 kasus baru penyakit paru yang berhubungan dengan pekerjaan. Di New York ditemukan 3\% kematian akibat penyakit paru kronik. Pneumokoniosis penambang batubara simpleks dapat berkembang menjadi kompleks dalam waktu 1 tahun. ${ }^{12}$ Di Indonesia angka sakit mencapai $70 \%$ dari pekerja yang terpapar debu tinggi. Sebagian besar penyakit paru akibat kerja mempunyai akibat yang serius yaitu terjadinya fungsi paru, dengan gejala utama yaitu sesak nafas. ${ }^{8}$

\section{Prevalensi}

Pneumokoniosis terbanyak adalah Silikosis, asbestosis dan pneumokoniosis batubara. Data di Australia tahun 1979-2002 menyebutkan, terdapat $>1000$ kasus pneumokoniosis terdiri atas $56 \%$ asbestosis, $38 \%$ silikosis dan $6 \%$ pneumokoniosis batubara. $^{9}$ Prevalensi pneumoconiosis batubara di berbagai pertambangan di 
Amerika Serikat dan Inggris bervariasi (2,5$30 \%$ ) tergantung besarnya kandungan batubara pada daerah pertambangan tersebut. ${ }^{12}$ Prevalensi pneumokoniosis di negara bagian Amerika pada tahun 1960 sekitar 30\% dan angka ini jauh menurun pada tahun 2002 hanya sekitar $2.5 \%$. setiap tahun angka kejadian pneumokoniosis berkurang hal ini dapat dikarenakan kontrol dari perusahaan yang kian meningkat. ${ }^{9}$

Prevalensi pneumokoniosis batu bara di Indonesia belum ada penelitian khusus mengenai prevalensi penyakit ini hanya pada skala kecil yang mencakup suatu perusahaan saja. ${ }^{10,11}$

\section{Silikosis}

penyebab dari silikosis adalah inhalasi dari Kristal silica biasanya di tempat kerja. pekerjaan tersering adalah pertambangan, sand blasting dan pengeboran. Silika terdapat dala bentuk Kristal dan amorf secara biologis lebih toksik dan fibrogenik. Intensitas pajanan terbesar akan memunculkan gejala. ${ }^{7}$ Klasifikasi Silikosis:

1. Silikosis akut. Dikarenakan pajanan ke kadar silika yang sangat tinggi dan muncul cepat.

Pasien datang dengan takipnea akut, batuk, sianosis, dan gagal nafas
2. Silikosis kronis. Terjadi akibat inhalasi silika Kristal dalam waktu lama disertai pembentukan

nodul fibrotik khas silikosis

3. Silikosis komplikata. Terjadi akibat perburukan dari silikosis kronis, disertai ekspansi dan dan

menyatunya nodul silikotik. serta terjadi dekstruksi dari parenkim paru yang massif.

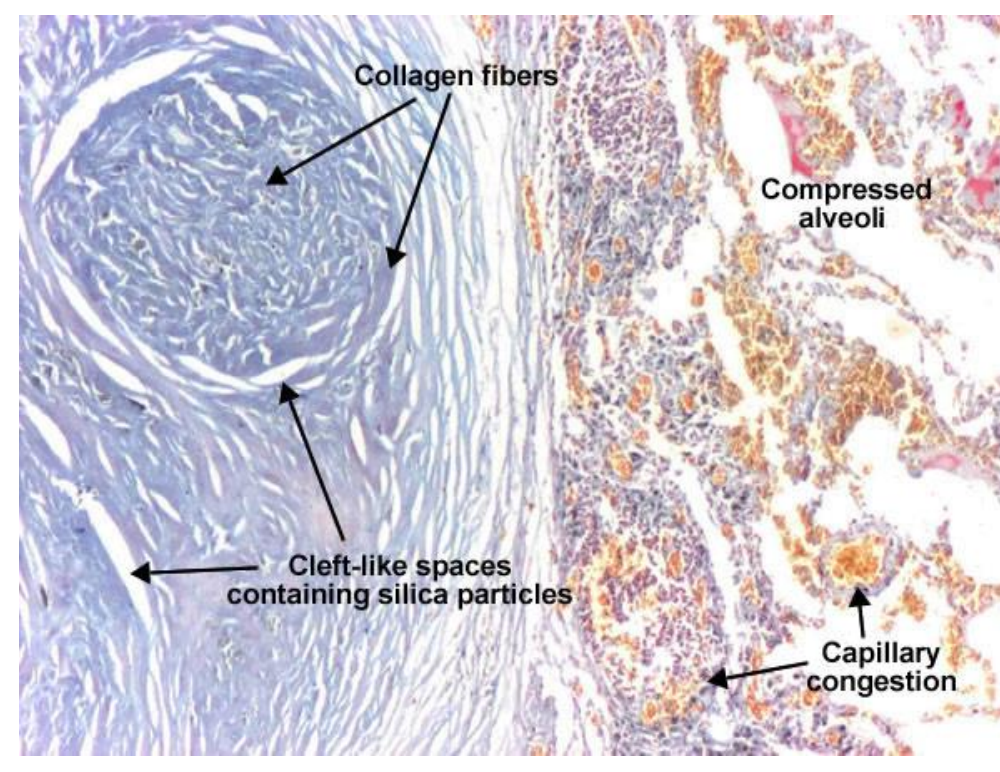

Gambar 1. silicosis paru ${ }^{23}$

\section{Diagnosis}

Ada tiga kriteria mayor yang dapat membantu untuk diagnosis pneumokoniosis. Ketiga kriteria tersebut adalah:

1. Pajanan yang signifikan terhadap debu mineral yang dicurigai dapat menyebabkan pneumokoniosis dan disertai dengan periode 
laten yang mendukung. Oleh karena itu, diperlukan anamnesis yang teliti mengenai kadar debu di lingkungan kerja, lama pajanan dan penggunaan alat pelindung diri serta kadang diperlukan pemeriksaan kadar debu di lingkungan kerja. Gejala seringkali timbul sebelum

kelainan radiologis seperti batuk produktif yang menetap dan atau sesak napas saat aktivitas yang mungkin timbul 10-20 tahun setelah pajanan.

2. Gambaran spesifik penyakit terutama pada kelainan radiologi dapat membantu menentukan jenis pneumokoniosis. Gejala dan tanda gangguan respirasi serta abnormalitas faal paru sering ditemukan pada pneumoconiosis tetapi tidak spesifik untuk mendiagnosis pneumokoniosis. ${ }^{4}$

3. Pneumokoniosis kemungkinan mirip dengan penyakit interstisial paru difus seperti sarkoidosis, idiophatic pulmonary fibrosis (IPF) atau interstitial lung disease (ILD) yang berhubungan dengan penyakit kolagen vaskular. $^{4,5}$

Pneumokoniosis penambang batubara kompleks biasanya disertai dengan gejala. Gejala yang timbul dapat berupa gejala respirasi seperti batuk berdahak yang cenderung menetap. Batuk pada CWP kompleks yang progresif dapat disertai dengan dahak berwarna kehitaman.
Hal ini biasanya diakibatkan oleh komplikasi infeksi yang terjadi pada penderita. $^{14,15}$ Gejala pernapasan lainnya seperti sesak napas terutama saat melakukan aktifitas dan nyeri dada. Gejala non respirasi yang mungkin terjadi adalah terdapat bengkak di kaki dan tungkai yang merupakan komplikasi lanjut. ${ }^{13,16}$ Pada pemeriksaan spirometri ditemukan penurunan nilai fungsi paru yang berarti. Tindakan preventif pada saat ini adalah untuk mencegah terjadinya komplikasi yang lebih parah. Untuk menegakkan diagnosis dari penyakit ini diperlukan anamnesis yang cermat terhadap: $12,17,18,23$

1. Keluhan yang dirasakan oleh penderita ditanyakan tentang adanya keluhan penyakit berupa

a. Batuk

- sifat batuk (keras/tidak)

- Waktu batuk(pagi/siang/malam/terusterusan)

b. Dahak (pagi/siang/malam/terusanterusan)

c. Nafas pendek

- waktu jalan cepat (jalan datar)

- Waktu berjalan 100 meter/ 1.5 km/atau lebih

d. Nyeri dada

b. Riwayat pekerjaan seperti lama bekerja, penempatan tugas, dan lingkungan. 
c. Kebiasaan penderita seperti menggunakan alat pelindung diri (APD) dan kebiasaan merokok.

\section{Pencegahan}

Pencegahan dari pneumokoniosis jenis ini yang paling penting dilakukan adalah menjauhi pajanan. Untuk penatalaksanaan dari kasus ini hanya diberikan terapi medikamentosa untuk mengatasi simtomatisnya dan mengurangi kemungkinan komplikasi yang akan muncul. ${ }^{15}$ Untuk penyebab yang dikarenakan CWP akan bersifat progresif sehingga tidak akan bisa sembuh hanya dengan menjauhi pajanan. Selebihnya para pekerja wajib dilakukan pemeriksaan berkala serta pengontrolan kadar debu di lingkungan kerja. ${ }^{3,19}$ Selain itu, pemeliharaan kesehatan juga penting seperti menghindari merokok yang akan memperburuk kondisi saluran pernapasan dan menghindari infeksi misalnya dengan melakukan vaksinasi. ${ }^{20,21}$

\section{PENUTUP}

\section{Kesimpulan}

Pneumokoniosis merupakan suatu penyakit akibat kerja yang dikarenakan oleh pajanan debu. Diantaranya debu silika, asbes, batu bara, berillium. Penyebab dari silikosis adalah inhalasi dari Kristal silica biasanya di tempat kerja. pekerjaan tersering adalah pertambangan, sand blasting dan pengeboran. Sedangkan untuk asbes adalah asbestosis.

$$
\text { Prevalensi untuk kasus }
$$
pneumokoniosis terbanyak adalah silikosis, asbestosis dan pneumokoniosis batubara. Data di Australia tahun 1979-2002 menyebutkan, terdapat >1000 kasus pneumokoniosis terdiri atas $56 \%$ asbestosis, $38 \%$ silikosis dan $6 \%$ pneumokoniosis batubara. Prevalensi pneumoconiosis batubara di berbagai pertambangan di Amerika Serikat dan Inggris bervariasi (2,5$30 \%$ ) tergantung besarnya kandungan batubara pada daerah pertambangan tersebut. Pencegahan adalah dengan menghindari pajanan debu dan melakukan pemeriksaan kesehatan berkala pada para pekerja khususnya pekerja tambang.

\section{Saran - saran}

Bagi perusahaan pertambangan hendaknya selalu melakukan screening terhadap para pekerja yang rutin setiap 3 bulan sekali.Dan pemerintah hendaknya mengawasi setiap pelaksanaan bagi industry pertambangan agar para pekerjanya aman. 


\section{DAFTAR PUSTAKA}

1. Sholikhah AM, Sudarmaji. Hubungan Karakteristik Pekerja dan Kadar Debu Total Dengan

Keluhan Pernapasan pada Pekerja Industri Kayu X di Kabupaten Lumajang. Kesehatan Lingkungan. 2015;1(1):1-2

2. National and Occupational Safety and Health Center. Pneumoconiosis in Indonesia. Presented

at: The ILO/OSH Center national training workshop. Prevention of pneumoconiosis. Using the

ILO International Classification of radiographs of pneumoconiosis, 2000. Jakarta, 19-22

November 2007.

3. Cowie RL, Murray JF, Becklake MR. Pneumoconiosis. In: Mason RJ, Broaddus VC, Murray JF, Nadel

JA, editors. Textbook of Respiratory Medicine. 4th Ed. Philadelphia: Elsevier Saunders; 2005: $1748-82$

4. Susanto, Agus Dwi. Pneumokoniosis. Pengembangan Pendidikan Keprofesian Berkelanjutan- IDI. J

Indon Med Assoc; 2011 (61): 12

5. Beckett, W. S. (2000-02-10). "Occupational respiratory diseases". The New England Journal of

Medicine. 342 (6):406-413.

6. Cullinan, Paul; Muñoz, Xavier; Suojalehto, Hille; Agius, Raymond; Jindal, Surinder; Sigsgaard,

Torben; Blomberg, Anders; Charpin, Denis; Annesi-Maesano, Isabella (May 2017). "Occupational

lung diseases: from old and novel exposures to effective preventive strategies". The Lancet.

Respiratory Medicine. 5 (5): 445-455.

7. Kumar,Cotran, Robbins Buku ajar Patologi Volume 2 Edisi 7; 2007;303-305

8. Andrik, F.C.A. Kajian Pembiayaan Sampah dalam Mendukung Pengelolaan Sampah di Pasar Johar
Kota Semarang. Skripsi. Fakultas Teknik Jurusan Perencanaan Wilayah dan Kota. Universitas

Diponegoro. 2010

9. Smith DR, Leggat PA. 24 years of pneumoconiosis mortality surveillance in Australia. J Occup Health.

2006; (48):309-13

10.Laney AS , Attfi eld MD . Quartz exposure can cause pneumoconiosis in coal workers . J Occup

Environ Med . $2009 ; 51$ ( 8 ): 867.

11. Bangun $\mathrm{U}$, Widjaya $\mathrm{M}$. Analisis epidemiologis pneumokoniosis berdasarkan $\mathrm{X}$ ray paru klasifikasi

standar international labour organization (ILO) pada pekerja tambang batu P.T. A di Bandung Jawa

Barat [Thesis]. Jakarta: Universitas Indonesia; 1998.

12. Antao VC, Petsonk EL, Sokolow LZ, et al. Rapidly progressive coal workers' pneumoconiosis in the

United States: geographic clustering and other factors. Occup Environ Med 2005: 670-4. 13.Schubauer-Berigan MK, Hein MJ, Raudabaugh WM, et al. Update of the NIOSH life table analysis

system: a person-years analysis program for the windows computing environment. Am J Ind Med

2011: 915-24.

14. Laney AS, Attfield MD. Coal workers' pneumoconiosis and progressive massive fibrosis are

increasingly more prevalent among workers in small underground coal mines in the United States

Occup Environ Med 2010; 67: 428-31

15. Miyazaki MaU H. Risk of lung cancer among Japanese coal miners on hazard risk and

interaction between smoking and coal mining. J Occup Health 2001: 43:6

16. Cohen RA. Is the increasing prevalence and severity of coal workers' pneumoconiosis in the United

States due to increasing silica exposure? Occup Environ Med 2010: 649- 50.

17. Hnizdo E, Vallyathan V. Chronic obstructive pulmonary disease due to occupational exposure to 
silica dust: a review of epidemiological and pathological evidence. Occup Environ Med

2003;60:237-43.

18. Silverman DT, Samanic CM, Lubin JH, et al. The diesel exhaust in miners study: anested casecontrol

study of lung cancer and diesel exhaust. J Natl Cancer Inst 2012: 855-68.

19. Centers for Disease Control and Prevention (CDC) . Coal workers' pneumoconiosis-related years of

potential life lost before age 65 years - United

States, 1968-2006

20. Demedts M, Nemey B, Elnes P.

Pneumoconioses. In: Gibson GJ, Gedder DM,

Costales U, Sterk PJ,

Cervin B, editor. Respiratory Medicine. 3rd

ed. London: Elsevier Science; 2003: 675-92

20.. Demedts M, Nemey B, Elnes P.

Pneumoconioses. In: Gibson GJ, Gedder DM, Costales U, Sterk PJ,

Cervin B, editor. Respiratory Medicine. 3rd

ed. London: Elsevier Science; 2003: 675-92

21.Kuempel ED, Wheeler MW, Smith RJ, et al.

Contributions of dust exposure and cigarette

smoking to

emphysema severity in coal miners in the

United States. Am J Respir Crit Care Med 2009;

180:

257-64.

22. Depnakertrans,Pedoman Diagnosis dan

Penilaian Cacat Karena Kecelakaan Dan

Penyakit Akibat

23.

Kerja, edisi 2, 2007:72

http://www.pathologyatlas.ro/pneumoconiosis-

silicosis.php diakses 2 September 2018

24. Holland JP. Asbestos in Hazardous Materials

Toxicology, Editors: JB Sullivan and GR

Krieger.

USA:Williams and Wilkins. 1992 